\title{
TANGGUNG JAWAB PEMERINTAH ATAS PERLINDUNGAN HUKUM GEOGRAFIS BERDASARKAN PASAL 20 TAHUN 2016
}

\author{
Maria Alfons \\ Widyaiswara Madya BPSDM Hukum dan HAM \\ Email: alfonsd334@yahoo.com
}

\begin{abstract}
ABSTRAK
Indonesia memiliki potensi sumber daya alam yang begitu banyak seperti; Kopi Kintamani, Kopi Toraya, Lada Bangka, Markisa Medan, Cengkeh dan Pala Ternate, Minyak Kayu Putih Ambon, Kayu Manis Bukit Tinggi dan masih banyak lagi produk-produk lokal lainnya yang dikatagorikan sebagai potensi indikasi geografis, dikarena tempat asal barang yang memiliki ciri ke-khas-an dari daerah yang bersangkutan, ciri khas produk yang dihasilkan tersebut memiliki mutu, kualitas dan karakter tertentu. Sebagai negara hukum yang mengatur indikasi geografis dalam Undang-Undang merek dan indikasi geografis, didasarkan hasil kesepakatan antara negara-negara maju dan negara-negara berkembang yang menanda tangani perjanjian-perjanjian internasional seperti TRIP's Agreement mewajibkan negara-negara anggotanya utuk menyusun peraturan nasionalnya dengan tujuan memberi perlindungan hukum terhadap adanya praktek atau tindakan curang dari negara lain atas produk atau barang yang dihasilkannya, contoh, kopi Toraja yang sejauh ini masyarakat mengakui bahwa reputasi kopi ini sudah sedemikian tinggi terkenal luas didalam dan diluar negeri, namun kenyataannya nama kopi ini bukannya didaftarkan oleh bangsa Indonesia tetapi didaftarkan sebagai merek oleh negara Amerika Serikat seperti, SULOTCO KALOSI COFFEE dengan gambar rumah Toraja, dengan nomor pendaftaran 74547000 , milik IFES Inc. Corporation California. Dalam rangka memberikan perlindungan hukum tanggung jawab pemerintahlah untuk membantu masyarakat melakukan pendaftaran sesuai amanat Pasal 53 ayat 3 (b) UU No 20 Thn 2016 tentang Merek dan Indikasi Geografis, yang mengatakan indikasi geografis mendapat perlindungan setelah terdaftar atas dasar permohonan yang diajukan oleh pemerintah
\end{abstract} daerah provinsi atau kabupaten/kota.

Kata Kunci : Indikasi Geografis; Perlindungan Hukum; Tanggung Jawab.

\section{ABSTRACT}

Indonesia has so many natural resource potentials such as; Kintamani Coffee, Toraja Coffee, Pepper Bangka, Medan Passion Fruit, Clove and Nutmeg Ternate, Ambon Eucalyptus Oil, Bukit Tinggi Cinnamon and many other local products that are categorized as potential geographical indications, due to the place of origin of goods that have special characteristics from the area concerned, the characteristics of the products produced have certain qualities and qualities.

As a legal state that regulates geographical indications in brand law and geographical indications, based on the results of agreements between developed countries and developing countries that sign international agreements such as the TRIP's Agreement requires member countries to draw up national regulations with the aim of giving legal protection against cheating practices or actions by other countries of the products or goods they produce, for example, Toraja coffee, which so far the community recognizes that the reputation of this coffee is already widely known at home and abroad, but in reality the name of this coffee is not registered by the Indonesian people but registered as a trademark by the United States of America such as, SULOTCO KALOSI COFFEE with a picture of Toraja house, with registration number 74547000, owned by IFES Inc. California Corporation.

In order to provide legal protection, it is the government's responsibility to help the public to register in accordance with the mandate of article 53 paragraph 3 (b) of Law No. 20 
Year 2016 concerning Geographical Marks and Indications, which says geographical indications are protected after being registered on the basis of an application submitted by the regional government province or district / city.

Keywords: Geographic indications, Legal Protection and Government Responsibility

\section{A. PENDAHULUAN}

Tuntutan adanya perlindungan terhadap Indikasi Geografis selanjutnya disingkat dengan IG dalam sistem hukum hak kekayaan intelektual tentunya merupakan suatu upaya yang diterapkan untuk melindungi produk-produk masyarakat lokal dalam negeri. Suatu merek1, sebagai pelaku bisnis ingin memperkenalkan atau menggunakan nama tempat, geografis untuk menjelaskan dari mana asal suatu barang.

Undang-Undang Nomor 20 Tahun 2016 tentang Merek dan Indikasi Geografis mengatur2, indikasi geografis pada Pasal 53 s/d 63, pada Pasal 1 ketentuan umum point 6 mengatakan Indikasi Geografis dilindungi sebagai suatu tanda yang menunjukkan daerah asal suatu barang yang karena faktor lingkungan geografis, termasuk alam, faktor manusia, atau kombinasi kedua faktor tersebut, memberikan ciri dan kualitas tertentu pada barang yang dihasilkan. Pada Pasal tersebut juga mengriskan bahwa Hak atas Indikasi Geografis adalah hak eksklusif yang diberikan oleh negara kepada pemegang hak Indikasi Geografis yang terdaftar, selama reputasi, kualitas, dankarakteristik yang menjadi dasar diberikannya pelindungan atas Indikasi Geografis tersebut masih ada.

Pasal 53 ayat (3) mengatakan indikasi geografis mendapat perlindungan setelah terdaftar atas dasar permohonan yang diajukan oleh:

\section{a. Lembaga yang mewakili masyarakat di kawasan geografis tertentu yang mengusahakan suatu barang dan/atau produk berupa:}

1. sumber daya alam;

2. barang kerajinan tangan; atau

3. hasil industri.

\section{b. Pemerintah daerah provinsi atau kabupaten/kota.}

Pada Pasal inilah landasan untuk menata perlindungan Indikasi Geografis atas produkproduk masyarakat lokal disesuaikan dengan tujuan yang dikehendaki oleh instrumen kebijakan dan mempunyai arti penting dalam kehidupan sosial masyarakat lokal.

Sejarah memperlihatkan bahwa indikasi geografis adalah suatu konsep yang universal yang mengindikasikan tanda dari suatu produk atau barang dengan nama daerah asal produksinya yang didaftarkan, seperti, the Ceylon, Champagne, Cognac, Beras basmati, Kristal Bohemian, yang merupakan produk luar negeri, dari Prancis, Australia, India yang kemudian telah dilindungi sebagai produk-produk komunitas dari negara pemiliknya.

Pada perkembangannya indikasi geografis kemudian mengalami internasionalisasi sejalan dengan meningkatnya perdagangan internasional di Eropa, pada abad ke-19, dan diaturlah yaitu dalam konvensi Paris 1883 yang memberikan pemikiran akan nilai ekonimis yang muncul pada indikasi geografis, sehingga mendorong negar-negara maju untuk membentuk suatu pengaturan internasional guna melindungi kekayaan alam dan industri mereka.

Dalam proses perundingan WTO (the agreement establishing World Trade organization) dan GATT (the general agreement on tarif and trade) menghasilkan adanya suatu perjanjian dengan tujuan utama untuk membuat hak kekayaan intelektual tidak menjadi halangan per-

\footnotetext{
$1 \quad$ Undang-Undang. No 20 Tahun 2016.

2 Pengaturan Indikasi Geografis dalam UU No. 20 Tahun 2018 tentang Merek dan IG, diatur pada Bab VII Pasal 53 sampai dengan Pasal 63.
} 
dagangan3 hal ini untuk memenuhi kesepakatan antara lain untuk:

1. Meningkatkan perlindungan terhadap HKI dari produk-produk yang diperdagangkan.

2. Menjamin prosedur pelaksanaan HKI yang tidak menghambat kegiatan perdagangan.

3. Merumuskan aturan serta disiplin mengenai pelaksanaan perlindungan terhadap HKI

4. Mengembangkan prinsip aturan dan mekanisme kerjasama internasional untuk menangani perdagangan barang-barang hasil pemalsuan atau pembajakan HKI4.

Begitupun yang tertuang dalam perjanjian TRIP's pada Pasal 22 s/d 24, pada Pasal 22 mengatur perlindungan IG adalah:

"For the purpose of this indications which indentily a good as originating in the territory of a member, or a region or locality in the territorry, where a given quality, reputation or other characteristic of the good is essensially atributable to is geographical origin". 5

(dalam perjanjian ini indikasi yang menandakan bahwa suatu barang yang berasal dari suatu teritori didalam negara anggota, atau daerah/lokasi dalam teritori tersebut, sehingga kualitas, reputasi dan karakter lainnya dari barang tersebut ditentukan secara essensial oleh tempat asalnya) Perlindungan Indikasi Geografis telah mengariskan bahwa negara-negara anggota akan mengatur sarana hukum bagi pihaknya yang berkepentingan untuk mencegah dari:

a) penggunaan cara penandaan dari suatu barang yang menyatakan bahwa barang itu berasal dari suatu daerah geografis yang lain daripada tempat asal aslinya yang menyesatkan masyarakat mengenai asal-usul geografis barang itu; dan

b) penggunaan yang merupakan tindakan persaingan tidak jujur

Indikasi Geografis memiliki peran yang strategis dalam dunia ekonomi, antara lain sebagai:

1. Sarana pelindung baik bagi produsen maupun konsumen

2. Sebagai sarana pemasaran

3. Sebagai sarana pembangunan bagi daerah pedesaan, dan

4. Sebagai sarana pemerataan ekonomi. 6

Indonesia memiliki potensi sumber daya alam yang begitu banyak seperti; Kopi Kintamani, Kopi Toraya, Lada Bangka, Markisa Medan, Cengkeh dan Pala Ternate, Minyak Kayu Putih Ambon, Kayu Manis Bukit Tinggi dan masih banyak lagi produk-produk lokal lainnya yang dapat dikatagorikan sebagai potensi indikasi geografis, dikarena tempat asal barang yang disebutkan merupakan ciri ke-khas-an dari daerah yang bersangkutan, yang sudah pasti produk yang dihasilkan memiliki mutu, kualitas dan karakter tertentu, akan tetapi produk-produk sebagaimana disebut diatas belum diberi perlindungan atasnya karena masih merupakan permohonan yang didaftarkan.

Pada intinya konsep dasar indikasi geografis sangat sederhana, tetapi ketika dikaitkan dengan perlindungan hukum, maka masing-masing negara menjadi sangat kompleks perlindungannya karena implementasinya tergantung pada pendekatan dari masing-masing negara terhadap peraturan atau kebijakannya, terutama yang berkaitan dengan persaingan sebab kualitas suatu produk apabila telah diketahui mutu, ciri khas dan karakteristik produk tersebut.

Dengan era globalisasi dibidang perdagangan dunia sekarang ini, dituntut pemerintah Indonesia mengkaji ketentuan hukum yang telah ada untuk melindungi indikasi geografis.

\footnotetext{
3 "The WTO Was Born Out of Negotation, everything the WTO does is the result negotiation ", < http: //www.wto.

4 Supanto. (2000). "Pembentukan TRIP's sebagai penetrasi budaya Dalam Wajah Hukum dalam Era Reformasi (Kumpulan Karya Ilmiah Menyambut 70 Thn Prof.Dr Sutjipto Raharjo, SH). Citra Aditya Bhakti, Bandung, hal 279.

5 The Agreement of the Trade Aspects of Intellectual Property Right, Including Trade in Counterfeit Good (TRIP'S Agreement) World Trade Organization 1994, article. 22.1.

6 Delphine Marie-Vivvien." Geographical Indication and International Legal Framework". Dalam Liputsan Khusus, Media HKI. Vol.II/No.1/April 2004, hal.29.
} $\operatorname{org}>$ 
Upaya ini harus dilakukan segera dengan mempertimbangkan adanya nama produk lokal Indonesia yang banyak diambil oleh pihak luar tanpa sepengetahuan masayarakat lokal yang kemudian dikembangkan menjadi miliknya sehingga memberi nilai ekonomi yang cukup besar bagi negaranya.

Fenomena ini seharusnya melekat langsung kepada produsen atau pemilik produk lokal yakni masyarakat itu sendiri melalui aparat pemerintah pusat maupun pemerintah daerah, seperti Dirjen Hak Kekayaan Intelektual Kementerian Hukum dan HAM RI, Dinas Peridustrian dan Perdagangan, Dinas Koperasi UMKM, aparat penegak hukum diantaranya pihak Kepolisian khususnya bagian Reserse, Kejaksaan, Hakim pada PN untuk dapat melindungi produk lokal yang dalam katagori indikasi geografis, ironisnya aparat pemerintah telah mengetahui perlindungan produk-produk lokal, tapi sisi lain masyarakat sendiri malah hampir dikatakan belum mengetahui tentang indikasi geografis dan perlindungannya.

Sebagai contoh beberapa waktu yang lalu kasus "Kopi Toraja" dari Indonesia yang terkenal telah didaftarkan di Jepang dan Amerika, yang tanpa sepengetahuan masyarakatnya sendiri kopi Toraja tersebut telah mempunyai reputasi sedemikian tinggi hingga dikenal luas baik didalam maupun di luar negeri, dan sejauh ini pula masyarakat Indonesia mengakui bahwa reputasi kopi toraja adalah sebagai bagian dari fenomena bisnis dan perdagangan suatu produk, dimana produk yang mempunyai reputasi Internasional akan diikuti oleh praktek peniruan, termasuk dalam bentuk dan cara penggunaan nama-nama produk yang sudah terkenal tersebut. Padahal Toraja sendiri adalah nama daerah di Sulawesi yang menunjuk indikasi geografis. Kopi Toraja yang sudah terkenal dan telah mempunyai reputasi, didaftarkan sebagai Merek dengan tiga sistim pendaftaran dengan menggunakan kata TORAJA dengan gambar rumah Torajanya seperti yang terlihat pendaftaran yang dilakukan sebagai berikut:

1. Merek Toarco Toraja Nomor Pendaftaran 75884722 milik Key Coffe, Inc Corporation Japan, menggunakan gambar rumah Toraja

2. Merek SULOTCO KALOSI TORAJA COFFEE Nomor Pendaftaran 74547036, milik IFES Inc. Corporation California

3. Merek SULOTCO KALOSI TORAJA COFFEE dengan gambar rumah Toraja Nomor Pendaftaran 74547000, milik IFES Inc. Corporation California.

Pendaftaran TORAJA COFFEE di Amerika Serikat tersebut tidak menyatakan kata TORAJA beserta gambar rumah Toraja yang merupakan simbol daerah Toraja sebagai hak eksklusif pendaftaran.7 Begitu juga yang terjadi pada Batik dari Jogya yang didaftarakan di Malaysia dan masih banyak produk lain yang banyak terjadi. Masalah seperti ini dibutuhkan hukum untuk melindunginya, sebab hukum itu hadir dan berperan sebagai pendorong terjadinya perubahan-perubahan dalam masa pembangunan dan menjamin kepastian hukum.

Pada Seminar Hukum Nasional III di Surabaya Tahun 2004 dalam pertimbangnya, menyatakan hukum merupakan salah satu sarana penting pembangunan, baik sebagai penjamin kepastian dan ketertiban dalam proses pembanguan maupun sebagai alat untuk mengadakan perubahan-perubahan kearah kemajuan untuk membina masyarakat yang dicita-citakan. 8 Hal tersebut mengambarkan bahwa fungsi hukum pada masa pembangunan di Indonesia diarahkan pada dua dimensi yaitu: i) hukum sebagai sarana pembaruan atau perubahan dalam masyarakat dan ii) hukum untuk menciptakan kepastian dan ketertiban, belum dioptimalkan secara utuh halmana karena adanya keterbatasan-keterbatasan dari pemerintah sebagai penggerak hukum itu sendiri.

Sebagaimana diutarakan diatas bahwa indonesia mempunyai sumber daya alam dan mempunyai keanekaragaman hayati begitu banyak dapat yang dipergunakan sebesar-besarnya

7 United States Patent and Trademark Office. (http://tess.uspto.gov/bin/gate.exe?f=doc\&state=fnd8p9.2.3)

8 K.W. Saleh, Seminar Hukum Nasional, Ghalia Indonesia, Jak. 1963-1979. Thn 1980. hal. 80. 
untuk perperekonomian rakyat dan bangsa, namun produk-produk lokal yang ada masih belum dapat dijaga, dilindungi dan dilestarikannya untuk kepentingan bangsa, padahal kalau dilihat secara tegas dalam Pasal 33 UUD 1945 telah menggariskan bahwa:

(1)Perekonomian disusun sebagai usaha bersama berdasar atas azas kekeluargaan.

(2)Cabang-cabang produksi yang penting bagi negara dan yang menguasai hajat hidup orang banyak dikuasai oleh negara.

(3)Bumi, air dan kekayaan alam yang terkandung didalamnya dikuasai oleh negara dan dipergunakan untuk sebesar-besarnya kemakmuran rakyat.

(4)Perekonomian Indonesia diselenggarakan berdasar atas demokrasi ekonomi dengan prinsip kebersamaan, efisiensi berkeadilan, berkelanjutan, berwawasan lingkungan, kemandirian, serta dengan menjaga keseimbangan kemajuan dan kesatuan ekonomi nasional.

(5)Ketentuan lebih lanjut mengenai pelaksanaan Pasal ini diatur dalam Undang-Undang Pasal 33 Undang Undang Dasar 1945 ini memberikan pesan moral dan pesan budaya dalam konstitusi Republik Indonesia di bidang kehidupan ekonomi. Pasal ini bukan sekedar memberikan petunjuk tentang susunan perekonomian dan wewenang negara mengatur kegiatan perekonomian, melainkan mencerminkan cita-cita, suatu keyakinan yang dipegang teguh serta diperjuangkan secara konsisten oleh para pimpinan pemerintahan.

Pasal ini diartikan bahwa rakyat diberikan kesempatan untuk mengelola dan memanfaatkan sumber daya alam dalam hal ini mengelola hasil bumi, air, kekayaan alam yang kemudian negaralah yang diberikan kuasa untuk mengatur dan mengurus sumber daya alam tersebut yang diperuntukkan kepada kemakmuran rakyatnya.

Pesan konstitusional tersebut tampak jelas, bahwa yang dituju adalah suatu sistem ekonomi tertentu, yang bukan ekonomi kapitalistik (berdasar paham individualisme), namun suatu sistem ekonomi berdasar kebersamaan dan berdasar atas asas kekeluargaan.

Mengenai asas kekeluargaan ini, semangat kekeluargaan yang menjadi landasan filosofis dalam Pembukaan Undang Undang Dasar 1945. Semangat kekeluargaan merupakan corak budaya bangsa Indonesia, oleh karena itu sikap, pemikiran, perilaku dan tanggungjawab seorang warga bangsa kepada kolektivitasnya berada di atas kepentingan individu...". Kemudian dikemukakan pula bahwa "...yang sangat penting dalam hal hidupnya negara ialah semangat para penyelenggara negara, semangat para pemimpin pemerintahan. Meskipun dibuat Undang Undang Dasar yang menurut kata-katanya bersifat kekeluargaan, apabila semangat para penyelenggara Negara, para pemimpin pemerintahan itu adalah bersifat perseorangan, Undang Undang Dasar itu pasti tidak ada gunanya dalam praktik ...".

Dari sudut pandang inilah, maka perlindungan hukum sangatlah dibutuhkan untuk melindungi produk-produk lokal milik masyarakat yang berpotensi indikasi geografis sebagai haknya, kemudian pengakuan diberikan kepada mereka berdasarkan pada sistem pendaftaran yang dilakukannya dan pemerintah memberikan hak moral dan hak eksklusif atas pemanfaatan hak yang ada untuk dipakai sebagai kepentingan bersama, sesuai dengan tata nilai dan prilaku masyarakat tersebut dalam bentuk ketentuan hukum.

Sehubungan dengan uraian latar belakang di atas, maka akan membahas permasalahan sebagai berikut: pertama, faktor-faktor apakah yang mempengaruhi Perlindungan Hukum atas Indikasi Geografis? kedua bagaimanakah bentuk Tanggung Jawab Pemerintah mendorong masyarakat lokal untuk melindungi indikasi geografis. Tujuan dari penulisan ini secara umum untuk mengetahui faktor-faktor apa saja yang menyebabkan indikasi geografis belum mendapatkan perlindungan hukum dan secara khusus untuk mengetahui bentuk tanggung jawab pemerintah untuk mendorong masyarakat melakukan perlindungan hukun atas produkproduk lokal yang berpotensi indikasi geografis 
Penulisan inidilandasipemikiranbahwatujuan hukum yang paling utama adalah menciptakan kepastian hukum sehingga fungsi hukum dapat berjalan dan mampu mempertahankan ketertiban. Kepastian hukum (rechmatigheid) merupakan salah satu nilai dasar hukum, selain keadilan (gerectigheit) dan kegunaan (zwechmatigheid/ doelmatigheid) sebagaimana dinyatakan oleh Gustav Radbruch dalam bukunya Einfuehrung in Die Rechtswissenchaft.9

Wujud ketertiban dan keadilan melekat pada perlindungan hukum termasuk perlindungan hukum atas hak kekayaan intelektual, yang juga manfaat dirasakan dalam bidang politik, ekonomi, sosisl budaya bahkan dari segi pertahanan keamananpun bisa meraih manfaat dari adanya perlindungan hukum baik itu secara ekonomi mikro maupun ekonomi makro, yang antara lain dapat memberikan dorongan untuk meningkatkan landasan teknologi nasional guna memungkinkan pengembangan teknologi yang lebih cepat lagi, dapat mewujudkan iklim yang lebih baik bagi tumbuh dan berkembangnya gairah mencipta sesuatu dibidang ilmu pengetahuan, seni dan sastra serta hasil karya dan karsa manusia.

Perlindungan hukum dibentuk selama ini untuk menghindari adanya pelanggaran yang dilakukan oleh negara-negara maju atas hak kekayaan intelektual seseorang, beberapa orang, sekelompok atau komunitas kelompok tertentu dari negara berkembang. Sebagai negara yang menganut konsep negara hukum, pemerintah sebagai regulator perlu mengantisipasi pelanggaran-pelanggaran hukum yang terjadi pada produk-produk milik masyarakat.

Perlindungan Hukum yang oleh Salmond serta Philipis M Hadjon dan Fitzgeral mengemukakan dua alasan : Pertama, permasalahan pokoknya yang difokuskan pada "Perlindungan Hukum" yakni perlindungan hukum terhadap produk-produk masyarakat lokal atas Indikasi Geografis ; kedua, dengan Teori Perlindungan Hukum diharapkan diperoleh landasan teoritik dalam menganalisis, memperbaharui, dan mengembangkan hukum untuk melindungi produk-produk lokal yang merupakan hak masyarakat lokal, juga merupakan upaya menggunakan hukum sebagai sarana mengintegrasikan dan mengkoordinasikan kepentingankepentingan dari negara-negara maju dalam pengambilan produk lokal berpotensi indikasi geografis

Menurut Salmond, Teori Perlindungan Hukum menguraikan bahwa hukum bertujuan mengintegrasikan dan mengkoordinasikan berbagai kepentingan dalam masyarakat karena dalam suatu lalu lintas kepentingan, perlindungan terhadap kepentingan tertentu hanya dapat dilakukan dengan cara membatasi kepentingan di lain pihak. 10.

Lebih lanjut Hadjon menjelaskan perlindungan hukum adalah suatu kondisi subjektif yang menyatakan hadirnya keharusan pada diri sejumlah subjek hukum untuk segera memperoleh sejumlah sumber daya, guna kelangsungan eksistensi subjek hukum yang dijamin dan dilindungi oleh hukum, agar kekuatannya secara terorganisir dalam proses pengambilan keputusan politik maupun ekonomi, khususnya pada distribusi sumber daya, baik pada peringkat individu maupun struktural. 11. perlindungan hukum lahir dari suatu ketentuan hukum dan segala peraturan hukum yang diberikan oleh masyarakat yang pada dasarnya merupakan kesepakatan masyarakat tersebut untuk mengatur hubungan prilaku antara anggota-anggota masyarakat dan antara perseorangan dengan pemerintah yang dianggap mewakili kepentingan masyarakat.

Hadjon lebih menitik beratkan pada " tindakan pemerintahan " (bestuurhendeling atau Administrative Action) dengan membedakan perlindungan hukum bagi rakyat dalam dua macam, yaitu: pertama perlindungan hukum yang preventif, bertujuan mencegah terjadinya sengketa, yang mengarahkan tindakan pemerintah bersikap hati-hati dalam pengambilan

9 Satjipto Rahardjo. Ilmu Hukum. Penerbit Alumni, Bandung, 1982, h. 20

10 Ibid ..Satjipto Raharjo. 2000.. 2000 hal.53.

11 Philipus M. Hadjon. 1987. Perlindungan Hukum Bagi Rakyat Indonesia, PT. Bina Ilmu, Surabay, p.2.

308 Maria Alfons | Tanggung Jawab Pemerintah Atas Perlindungan Hukum Geografis ... 
keputusan berdasarkan diskresi ; dan kedua perlindungan hukum represif, bertujuan untuk menyelesaikan terjadinya sengketa, termasuk penanganannya dilembaga peradilan.

\section{B. METODE PENELITIAN}

Metode pendekatan dalam penelitian ini menggunakan metode yuridis normatif (legal research) Pendekatan yuridis karena menganalisa data yang berpedoman kepada normanorma hukum sebagaimana konsepsi legisme positivisme yang menekankan hukum identik norma-norma tertulis, dalam hal ini peraturan perUndang-Undangan dibidang HKI. Penelitian dilakukan dilakukan di Jakarta pada Direktorat Jenderal Kekayaan Intelektual. Jenis data yang akan dianalisis menggunakan data primer dan data sekunder. Sumber data diambil dari Ditjen kekayaan intelektual sebagai data primer. Sedangkan data sekunder yang digunakan meliputi bahan hukum primer yaitu peraturan perUndang-Undangan di bidang merek dan indikasi geografis bahan hukum sekunder yaitu bahan-bahan yang memberikan informasi atau hal-hal yang berkaitan dengan data primer serta implementasinya. Bahan hukum sekunder diambil dari data resmi pada instansi pemerintah, buku, makalah maupun karangan ilmiah, surat kabar/ majalah yang berhubungan dengan indikasi geografis. Adapun bahan hukum tersier merupakan bahan yang memberikan penjelasan terhadap bahan hukum primer dan bahan hukum sekunder, meliputi kamus, black law dictionary, dan ensiklopedia. Pengumpulan data primer menggunakan teknik wawancara. Tujuan wawancara antara lain memperoleh data tentang persepsi seseorang, mengumpulkan data mengenai motivasi seseorang atau mendapatkan data mengenai perilaku yang sifatnya pribadi.

\section{PEMBAHASAN}

\section{Perlindungan Hukum Terhadap Indikasi Geografis}

Secara umum HKI terdiri atas dua hal, yaitu hak kekayaan industri dan hak cipta. Hak kekayaan industri terdiri dari Paten, Merek dan Indikasi Geografis, Rahasia Dagang, Desain Industri, Desain Tata Letak Sirkuit Terpadu, Variates Tanaman, sedangkan hak cipta terdiri dari hasil karya asli dibidang ilmu pengetahuan, seni dan sastra. Sebagai negara kepulauan yang memiliki pengetahuan, tradisi dan budaya dan tropis yang menghasilkan berbagai macam barang/produk dari sumber alam dan hayati yang mempunyai potensi nilai ekonomi yang tinggi sudah seharusnya mempunyai suatu konsep perlindungan hukum atas barang/produk yang ada, sehingga dengan nilai ekonomi yang ada dapat mewujudkan suatu konsep negara kesejahteraan, sebab negara kesejahteraan akan berlandaskan pada sistem ekonomi pasar yang bertujuan untuk mewujudkan kesejahteraan bagi masyarakatnya.

Bagi Indonesia ketentuan indikasi geografis masuk dalam ketentuan hukum merek, sekilas terlihat merek dapat melindungi indikasi geografis padahal sistem perlindungan merek berbeda dengan sistem perlindungan indikasi geografis, dimana merek dilindungi secara individual sedangkan indikasi geografis dilindungi secara komunal, kemudian sifat merek tidaklah menunjukan kualitas produk, indikasi geografis menunjukan kualitas, reputasi dan karakteristik termasuk georafis dimana produk tersebut berada di wilayah penghasilnya.

Pada Undang-Undang Nomor 15 Tahun 2001 tentang Merek pada Pasal 56 merumuskan Indikasi Geografis yang merupakan sub bagian Merek yang dilindungi sebagai suatu tanda yang menunjukkan daerah asal suatu barang yang karena faktor lingkungan geografis, termasuk alam, faktor manusia, atau kombinasi kedua faktor tersebut. Kemudian penjelasan Pasal ini mengartikan, Indikasi Geografis adalah suatu indikasi atau identitas dari suatu barang yang 
berasal dari suatu tempat, daerah atau wilayah tertentu yang menunjukkan adanya kualitas, reputasi dan karakteristik termasuk faktor alam dan faktor manusia yang dijadikan atribut dari barang tersebut. Tanda yang digunakan sebagai indikasi geografis dapat berupa etiket atau label yang dilekatkan pada barang yang dihasilkan. Kemudian artian Tanda tersebut dapat berupa nama tempat, daerah, atau wilayah, kata, gambar, huruf, atau kombinasi dari unsurunsur tersebut. Pengertian nama tempat dapat berasal dari nama yang tertera dalam peta geografis atau nama yang karena pemakaian secara terus-menerus sehingga dikenal sebagai nama tempat asal barang yang bersangkutan. Perlindungan atas indikasi-geografis meliputi barang-barang yang dihasilkan oleh alam, barang hasil pertanian, hasil kerajinan tangan; atau hasil industri tertentu lainnya".

Perubahan Undang-Undang Nomor 15 tahun 2001 tentang Merek ke Undang-Undang Nomor 20 tahun 2016 tentang Merek dan indikasi Geografis pada ketentuan umum angka 6 mengatakan indikasi geografis adalah suatu tanda yang menunjukan daerah asal suatu barang dan atau produk yang karena faktor lingkungan geografis termasuk faktor alam, faktor manusia atau kombinasi dari kedua faktor tersebut memberikan reputasi, kualitas dan karakteristik tertentu pada barang dan atau produk yang dihasilkan.

Demikian juga Peraturan Pemerintahan Nomor 51 Tahun 2007 tentang Indikasi Geografis dan Keputusan Menteri Hukum dan Hak Asasi Manusia Republik Indonesia Nomor M.HH.01. HI..02.01.Tahun 2008 tentang Tim Ahli Indikasi Geografis (TAIG) adalah sebagai landasan operasional dalam memproses dan mengadministrasikan semua pengajuan pendaftaran indikasi geografis yang sudah diajukan oleh Pemohon kepada Direktorat Jendral Hak Kekayaan Intelektual diatur untuk mempermudah akan perlindungan hukum.

Patut diketahui indikasi geografis, telah diatur di beberapa ketentuan terlebih dahulu untuk melindungi kekayaan intelktual merekan seperti, ketentuan Convensi Paris, Madrid aAgreement dan Lisbon Agremeent yang kemudian dipertegas lagi dalam ketentuan TRIPs Agreement. Convensi Paris pada Pasal 1 (2) menyebutkan perlindungan tentang "Indication of Source" atau "Appelation of Origin" yang merupakan salah satu bagian dari obyek perlindungan konvensi yaitu: "The Protection of Indrustrial Property has as its object patents, utility models, industrial design, trade marks, service marks, trade names, indication of source or appelation of origin, and the repression of unfair competition"

Madrid Agreement memberikan rumusan perlindungan yang lebih luas tentang Indikasi Geografis yang dirumuskan dalam Pasal 1 (1) sebagai berikut:"All goods bearing a false or deceptive indication by which one of the countries to which this agreement applies or a place situated therein, is directly or indirectly indicated as being the country or place or origin shall be seized on importation into any of the said countries."

Lisbon Agreement mengatur tentang Indikasi Geografis secara lebih luas lagi yang ruang lingkup pengaturannya mencakup sistem pendaftaran atas Indikasi Geografis. Dalam Agreement tersebut Indikasi Geografis dinyatakan sebagai Appelation of Origin yang secara definitif dirumuskan dalam Pasal 2 WIPO, sebagai berikut: "The geographical name of a country, region, or locality, which serves to designate a product originating there in, the quality and charateristic of which are due exclusively or essentially to the geographical environment, including natural and human factors".

Dilindunginya indikasi geografis ke dalam sistim perlindungan hukum karena mempunyai nilai ekonomi atas barang atau produk yang berasal dari masyarakatnya. Negara-negara berkembang seperti di Cina, Vietnam, Thailand, Indonesia, Meksiko, Korea dan lain sebagainya, melihat indikasi geografisnya memiliki peran yang strategis dalam dunia ekonomi, antara lain sebagai: 
1. Sarana pelindung baik bagi produsen maupun konsumen

2. Sebagai sarana pemasaran

3. Sebagai sarana pembangunan bagi daerah pedesaan, dan

4. Sebagai sarana pemerataan ekonomi.

Pemerintah Indonesia sudah sepantasnya melindungi apa yang menjadi hak-hak masyarakat lokal atas sumber daya alam dan hayati, sekalipun disatu sisi masyarakat sendiri belum menyadari bahwa arti kemanfaatan dan nilai ekonomi yang didapat dari sumber daya alam dan hayati tersebut memberikan kesejahteraan bagi masyarakat setempat dan memberikan keberhasilan pada sektor perindustrian dan perdagangan.

Indikasi geogrfis merupakan salah satu tanda dari produk yang dihasilkan yang dikarenakan faktor alam ataupun faktor geografis, pengaturan perlindungan akan diberikan kepada lembaga yang mewakili masyarakat dikawasan geografis tertentu yang mengusahakan suatu barang atau produk yang meliputi, sumberdaya alam, barang kerajinan tangan dan hasil industri.

Dalam hal lembaga mewakili masyarakat untuk melakukan pendaftaran atas barang atau produk maka terlintas akan ada perlindungan terhadap sumber daya alam yang dimilikinya, walaupun dalam pendaftaran mewajibkan syarat-syarat yang harus terpenuhi. Beberapa contoh tanda yang dapat dikatakan sudah cukup terkenal yang menyangkut nama geografis dan telah mendapat perlindungan hukum dari negara pemiliknya berdasarkan pada pendaftaran seperti: Champagne, Cognac, Havana dan Tequila. Nama-nama produk tersebut menunjukkan asal tempat, negara atau wilayah dimana produk tersebut dihasilkan.

Dengan kata lain, ketika seseorang menyebut nama suatu produk dengan nama geografis maka orang akan mengaitkan produk tersebut dengan tempat asal dari produk yang bersangkutan, halmana karena kekhasan suatu produk seringkali juga menunjuk pada kualitas dan karakteristik, maka indikasi geografis dapat berfungsi sebagai identitas reputasi dari produk asli yang berasal dari daerah atau wilayah tertentu. Dengan adanya unsur tanda tersebut dapat dikatakan mempunyai nilai kemanfaatan dan nilai ekonomi.

Dengan demikian, penekanan konsep perindungan atas indikasi geografis terlihat pada ciri khas, kualitas, reputasi dan karakteristik yang melekat dengan lingkungan geografis.

Di Indonesia indikasi geografis sendiri memiliki signifikan yang cukup tinggi, dikarenakan beberapa sebab:

1. Sebagai penandatangan perjanjian TRIP's, adanya sistem perlindungan indikasi geografis yang implementatif ditingkat nasional dan akan meningkatkan integritas Indonesia dimata dunia internasional;

2. Adanya keuntungan dari negara pemula untuk memilih sistem indikasi geografis yang cocok dengan kepentingan nasional dalam masa transisi ini. Karena sisitem implementasi perlindungan indikasi geografis yang sekarang berlaku secara internasional masih amat beragam dan belum disepakati bersama, Indonesia dapat mempergunakan kedaulatannya untuk membangun sistem sendiri yang paling cocok bagi kepentingan nasional, sesuai dengan nilai-nilai masyarakat sendiri, sambil berpijak pada prinsip-prinsip dasar perjanjian TRIP's;

3. Karakteristik kepemilikan indikasi geografis yang kolektif atau komunalistik sejalan dengan nilai-nilai ketimuran dan keindonesiaanyanglebihmenghargaikepemilikan bersama daripada kepemilikan pribadi;

4. Keharusan adanya kaitan atau hubungan yang erat (strong link) antara nama atau indikasi produk dengan kondisi geografis asal produk dalam rezim indikasi geografis tampak sejalan dengan sifat-sifat hukum masyarakat adat yang selalu menjunjung kebergantungan dan kelekataneksistensinyadengantanahasal.PotensiIndikasigeografisinidapatdikembangkan 
untuk melindungi produk-produk masyarakat adat dan komunitas lokal yang umumnya memang dinamai bukan dengan nama individu, tetapi nama tempat asal suatu produk yang akan dilindungi dengan indikasi geografis;

5. Jangka waktu perlindungan indikasi geografis yang terus menerus membuatnya berpotensi untuk melindungi keberlangsungan aset bangsa aset historis suatu komunitas lakal agar tetap tinggal dan bermanfaat bagi bangsa ataukelompok masyarakat pengembangnya sendiri;

6. Dinegara maju sekalipun, misalnya Prancis, indikasi geografis merupakan salah satu rezim HKI yang telah terbukti meningkatkan derajat ekonomi komunitas lokal yang miskin, terpencil, dan hanya memiliki satu sektor ekonomi andalan, untuk menjadi basis penguatan infrastruktur lokal yang independent.12

Dari unsur-unsur tersebut diatas, tampak jelas bahwa perlindungan terhadap indikasi geografis sangat penting dilakukan di Indonesia, namun di satu sisi perlu disadari bahwa kenyataannya ironi bagi bangsa Indonesia tercatat sebagai negara yang banyak melakukan pelanggaran dibidang HKI, dan merugikan negara luar dengan menggunakan hak kekayaan intelektualnya.

Emawati Yunus,13 mengatakan ada beberapa manfaat dari pendaftaran atas indikasi geografis yaitu:

1. Indikasi Geografis akan melindungi pengusaha dari persaingan yang tidak sehat;

2. Membantu mempromosikan produk-produk nasional ke pasar internasional;

3. Memberi reputasi iternasional;

4. Mendorong partisipasi masyarakat untuk memiliki produk bersama hasil kekayaan alam;

5. Memajukan industri pertanian rakyat;

6. Memberi nilai tambah bagi produk tersebut;

7. Bagi konsumen, itu menjadi jaminan kualitas barang;

8. Mendukung perkembangan dunianusaha yang kompetetif dan spesifik dipasar global, serta memberikan reputasi internasional dibidang eksport pada produk yang berkarakter dan memiliki tradisi kebudayaan daerah.

Pada Pasal (2) Peraturan Pemerintah Nomor 51 tahun 2007 tentang Indikasi Geografis, dari segi objek, yang dilindungi yaitu:

a. Barang-barang yang dihasilkan oleh alam;

b. Barang-barang hasil pertanian;

c. Hasil kerajinan tangan;

d. Hasil industri tertentu.

Apalagi untuk meningkatkan taraf kehidupan ekonomi masyarakat juga, pemanfaatannya pada hasilnya dapat mensejahterakan masyarakat setempat, sebagaimana yang dikemukakan oleh Abdul Bari Azed 14 bahwa pemanfaatan perlindungan atas IG:

1. Memberikan perlindungan hukum pada produk yang berbasisi IG;

2. IG dapat digunakan sebagai pemasaran produk pada perdagangan dalam dan luar negeri

3. Memberikan nilai tambah pada produk yang berpotensi IG didaerahdan meningkatkan kemampuan ekonomi daerah;

4. Meningkatkan reputasi produk IG pada perdaganagan global

5. Adanya persamaan perlakuan atas IG dan promosi IG diluar; dan

12 Denis Rochart, La Protection Internationale des Indications Geographiques, Presses Universitaires de France, Paris, 2002, hal.359.

13 Emawati Junus, Seminar IG ke Dirjen HKI, Tgl 6-7 Thn 2004 Kerjasama Ditjen HKI dan EC-ASEAN Cooperation on Intellectual Property Right (ECAP) II.

14 Abdul Bari Azed, Kepentingan Negara Berkembang terhadap IG, Sumber Daya Genetik dan Pengatahuan Traditional, Lembaga Pengkajian Hukum International Fak Hukum UI kerjasama dengan Ditjen HKI, Thn 2005, Hal 11.

312 Maria Alfons | Tanggung Jawab Pemerintah Atas Perlindungan Hukum Geografis $\quad$... 
6. IG sebagai salah satu alat untuk menghindari persaingan curang.

Indikasi Geografis sendiri memberikan perlindungan kepada pemilik atau pemegang indikasi geografis yang sah untuk memiliki beberapa hak dan kewajiban yang harus dijaga dan dipelihara oleh pemilik atau pemegang indikasi geografis mereka secara terdaftar, yang antara lain:

1. Hak-hak yang dimiliki:

a) Mengajukan Perubahan Buku Persyaratan Indikasi Geografis;

b) Melakukan Gugatan atas Pelanggaran Indikasi Geografis Terdaftar;

c) Permohonan Penetapan Sementara Pengadilan; dan

d) Hakim dapat memerintahkan pelanggaran untuk menghentikan kegiatan pembuatan, perbanyakan, serta memerintahkan pemusnahan etiket indikasi-geografis yang digunakan secara tanpa hak tersebut.

2. Pemakaian suatu tanda Indikasi-geografis yang bersifat komersial, baik secara langsung maupun tidak lasngsung atas barang yang dilindungi atau tidak dilindungi atas maksud:

a. Untuk menunujukan bahwa barang tersebut sebanding kualitasnya dengan barang yang dilindungi oleh Indikasi-geografis;

b. Untuk mendapatkan keuntungan dari pemakaian tersebut; atau

c. Untuk mendapatkan keuntungan atas reputasi Indikasi-geografis;

d. Pemakaian Indikasi-geografis yang dapat menyesatkan masyarakat sehubung asalusul geografis barang itu;

3. Pemakaian Indikasi-geografis secara tanpa hak sekalipun tempat asal dinyatakan;

4. Peniruan atau penyalahgunaan lainnya yang dapat menyesatkan sehubung dengan asal tempat barang atau kualitas barang yang tercermin dari pernyataan yang terdapat pada:

a. Pembungkus atau kemasan;

b. Keterangan dalam iklan;

c. Keterangan dalam dokumen mengenai barang tersebut;

d. Informasi yang dapat menyesatkan mengenai asal usulnya (dalam hal pengepakan barang dalam suatu kemasan); atau

5. Tindakan lainnya yang dapat menyesatkan masyarakat luas mengenai kebenaran asal barang tersebut.

Masalah pendaftaran atas indikasi geografis untuk mendapat perlindungan didasarkan pada prosedur atau tata cara pendaftaran yang berada pada Peraturan Pemerintah Nomor. 51 tahun 2007 tentang Indikasi Geografis. Membahas perlindungan hukum akan dilihat dari lahirnya suatu ketentuan hukum yang segala peraturannya dibuat oleh masyarakat yang pada dasarnya merupakan kesepakatan masyarakat tersebut untuk mengatur hubungan perilaku antara anggota-anggota masyarakat dan antara perorangan dengan pemerintah yang dianggap mewakili rakyat. 15

Menurut Aquinas, kebaikan (goodness) dan kebahagiaan (happiness) sebagai tujuan akhir dari semua tindakan manusia merupakan landasan moral bagi hukum positif. Melalui ajaran ini tidak sulit untuk memahami adanya suatu aspirasi yang menghendaki pengakuan terhadap hak kolektif atas warisan budaya (cultural heritage).

15 Saphor Manulu Hutagalung, Hak Cipta dan Penerapannya didalam Pembangunan. Akademi Prasindo.Jakarta. 2000. hal. 94 
Pandangan para ahli berkaitan dengan perlindungan hukum diatas. lebih diarahkan pada perlindungan hukum akibat instrument hukum yang belum menjamin pemenuhan hak-hak masyarakat terhadap pemakaian atas sumber daya alam yang dilakukan oleh pihak luar yang mempunyai nilai ekonomi. Pasal 33 Undang Undang Dasar 1945, ayat (1) menyatakan: “... Perekonomian disusun sebagai usaha bersama berdasar atas asas kekeluargaan...". Perekonomian disusun artinya tidak dibiarkan tersusun sendiri secara bebas (diatur oleh pasar). Susunan yang dimaksudkan adalah "usaha bersama" (berdasar suatu mutualisme yang menunjukkan perbedaannya dari usaha swasta yang didorong oleh self-interest). Asas kekeluargaan (brotherhood) yang bukan kinship nepotistik, sebagai pernyataan adanya tanggungjawab bersama untuk menjamin kepentingan, kemajuan dan kemakmuran bersama layaknya makna brotherhood.

Pasal 33 Undang Undang Dasar 1945, ayat (2) menyatakan: “... Cabang-cabang produksi yang penting bagi Negara dan yang mengusai hajat hidup orang banyak dikuasai oleh Negara...". Perkataan "yang penting bagi negara" dapat diinterpretasikan dengan tanggungjawab negara, yaitu “...untuk melindungi bangsa Indonesia dan seluruh tumpah darah Indonesia dan untuk memajukan kesejahteraan umum, mencerdaskan kehidupan bangsa dan ikut melaksanakan ketertiban dunia berdasar kemerdekaan, perdamaian abadi dan keadilan sosial...". Secara singkat dikatakan bahwa "penting bagi negara" adalah cabang-cabang produksi strategis. Interpretasi bahwa "dikuasai" oleh negara tidak harus diartikan "dimiliki" oleh negara (artinya boleh dimiliki oleh usaha swasta atau asing) hanya dapat diterima dalam konteks jiwa Pasal 33 Undang Undang Dasar 1945. Maksudnya pemerintah benar-benar memegang kendali, sehingga ayat (3) Pasal 33 Undang Undang Dasar 1945 terlaksana.

Sebagai negara yang menganut konsep negara hukum, pemerintah sebagai regulator perlu mengantisipasi pelanggaran-pelanggaran hukum yang terjadi pada produk-produk milik masyarakat, guna mewujudkan keadilan. Philipus M. Hadjon menjelaskan perlindungan hukum adalah suatu kondisi subjektif yang menyatakan hadirnya keharusan pada diri sejumlah subjek hukum untuk segera memperoleh sejumlah sumber daya, guna kelangsungan eksistensi subjek hukum yang dijamin dan dilindungi oleh hukum, agar kekuatannya secara terorganisir dalam proses pengambilan keputusan politik maupun ekonomi, khususnya pada distribusi sumber daya, baik pada peringkat individu maupun struktural. 16

\section{Faktor-faktor yang mempengaruhi Perlindungan Hukum atas Indikasi Geografis}

Sejumlah kasus yang dialami di negara-negara berkembang termasuk Indonesia mengenai penyalagunaan sumber-sumber daya hayati, sumber daya genetika atau yang berhubungan dengan sumber daya alam perlu disoroti dan menekan urgensi untuk pemusatan perhatian agar dapat melindunginya dari persaingan bisnis tidak sehat yang dilakukan oleh negara-negara maju.

Perlindungan yang diberikan berupa sistem pendaftaran karena dengan pendaftaran masyarakat akan mendapatkan hak khusus untuk mengembangkan hasil sumber daya yang ada atau produk-produk lokalnya yang kemudian kegunaanya diperuntukkan bagi kepentingan ekonomi masyarakat itu sendiri.

Ketika TRIP's memberikan suatu sistim perlindungan secara internasional menyangkut investasi dan teknologi dibidang indikasi geografis, seharusnya pemerintah Indonesia memperjuangkan hak-hak masyarakat lokal terutama mengenai sumber daya alam, karena mempunyai ciri dan karakteristik tersendiri, yang kemudian dapat terhindar dari adanya upaya pengambilan produk secara tanpa hak oleh negara-negara lain, ini sangat rentan terhadap

16 Philipus M. Hadjon. 1987. Perlindungan Hukum Bagi Rakyat Indonesia, PT. Bina Ilmu, Surabay, p.2.

314 Maria Alfons | Tanggung Jawab Pemerintah Atas Perlindungan Hukum Geografis ... 
peniruan akan produk-produk lokal seperti kasus pada gambaran kopi Toraja. Kejadian ini menggambarkan bahwa ketentuan indikasi geografis belum sepenuh diterapkan untuk melindungi produk-produk dari masyarakat lokal.

Indonesia sendiri harus bisa memberlakukan sistem perlindungan Indikasi Geografis secara cepat, sebab Indonesia mempunya banyak daerah kepulauan yang memiliki aset-aset sumber daya alam, kerajinan tangan dan hasil industri dengan berbagai karakteristik yang berbedabeda, sehingga tidak dijadikan komiditas bagi negara lain yang dapat menguntungkan mereka.

Dasar perlindungan dilakukan karena masyarakat masih belum mengenal secara utuh akan indikasi geografis yang ada sekitar wilayah mereka, yang mempunyai nilai ekonomi dalam menunjang kesejahteraannya. Selama ini masyarakat hanya melakukan pendaftaran sumber daya alam, kerajinan tangan dan hasil industri berdasarkan sistem hukum merek, sebab dengan pendaftaran merek tersebut dapat memberikan keuntungan secara pribadi, bukan keuntungan secara kebersamaan. Ketidak tahuan masyarakat akan perlindungan atas indikasi gegrafis didasarkan faktor-faktor mendasar yakni faktor substansi, faktor struktur dan budaya hukum.

\section{a) Faktor substansi}

Secara konseptual, subtansi hukum menunjukan pada aturan atau ketentuan dalam peraturan perundangan yang ada.17 Oleh karenanya Ketentuan IG yang ada dalam UU Merek dan Indikasi Geografis, menjadi fokus kajian dan apa yang disebut Yehezkel Dror 18 sebagai hukum subtantif (subtantive law), pembahasan tentang IG perlu dikaitkan dengan peraturan perUndang-Undangan lainnya, baik dalam kaitan vertikal maupun horisontal.

Secara vertikal IG dalam ketentuan merek merupakan penjabaran dari UUD 945 pada Pasal Pasal 5 ayat (1) Pasal 20 dan Pasal 33. Berdasarkan subtansi IG melekat hak ekonomi dan hak moral, hak ekonomi adalah hak untuk mendapat manfaat atas hasil yang didapat dari sumber daya alam, kerajinan tangan dan hasil industri, sedangkan dan hak moral adalah hak yang melekat pada masyarakat yang memproduksi sumber daya alam yang ada.

Apabila ditelusuri lebih jauh mengapa masyarakat belum melakukan pendaftaran atas IG hal ini karena : 1) masyarakat belum mengetahui akan ketentuan IG yang menyatu dengan ketentuan Merek, selama ini memandang merek lebih dominan; 2) masyarakat beranggap sumber daya alam, kerajinan tangan dan hasil industri hanya dapat dipergunakan sekali pemakaian artinya produk-produk tersebut tidak perlu didaftarkan apabila terjadi penjualan maka dianggap selesai; 3) masyarakat khususnya pelaku usaha lebih senang mendaftarkan sumber daya alam, kerajinan tangan dan hasil industri yang dikelola dengan sistem hukum merek, sebab merek banyak memberikan manfaat dan dapat mencapai keuntungan secara individu (kesulitan bagi masyarakat lokal untuk melakukan pendaftaran, karena masyarakat lokal tidak mengetahui bagaimana melakukan penelusaran untuk menjelaskan uraian-uraian yang tertera pada buku persyaratan tersebut. Penelusaran uraian membutuhkan waktu yang cukup panjang mengakibatkan masyarakat belum siap untuk melakukan pendaftaran) ${ }^{19}$

\section{b) Faktor Struktur}

Struktur hukum untuk menangani IG harus merupakan struktur yang terbuka dan kompeten. L. Friedman 20 mengatakan struktur hukum adalah, sub sistem yang berkaitan dengan personil,

17 L. M. Friedman, TheLegal System: A Social Science Perpektive, Russel Sage Foundation New York, 1977. hal 153

18 Yehezkel Dror, Ventures and Policy Scince Conceptsand Application, New York, Elsevier, 1981. hal 170.

19 Wawancara dengan Idrus

20 Ibid L. M. Fridman, The Legel Sistem...h. 14. 
sarana, dan prasarana yang dibutuhkan dalam menjalankan hukum. jika dikaitkan dengan sistem hukum dari Yehezkel Dror maka unsur-unsur itu paralel dengan sub sistem personal, organizations, and resources 21

Dalam konteks ini faktor hukum akan dilihat berkaitan dengan kapasitas personil, organisasi dan fasilitas yang dimiliki instansi-instansi yang bertugas mendesiminasi UU Merek dan IG kepada masyarakat. Ditjen KI Kementerian Hukum dan HAM RI adalah merupakan lembaga diberikan kepercayaan oleh pemerintah Indonesia untuk menjalankan amanat UU dibidang KI. Tugas Dirjen KI untuk melaksanakan sistem KI nasional secara terpadu, disamping itu juga melaksanakan koordinasi dengan instansi-instansi terkait baik yang berada di pusat maupun di daerah serta memperluaskan jaringan-jaringan kerjasama regional dan internasional. Tanggung jawab tetap dilakukan oleh Ditjen KI, namun berkoordinasi dengan instansi lain yang juga sama-sama bergerak dibidang kekayaan intelektual belum dapat berperan dengan baik, dalam hal ini belum ada Road Map dari masing-masing instansi tentang peran dan fungsi atas pengembangan IG22.

Dalam fungsinya sebagai perpanjangan tangan di daerah, Kantor Wilayah Kementerian Hukum dan HAM diberikan tugas untuk meneriman permohonan pendaftaran KI, yang mulai dari penerimaan permohonan pendaftaran, perpanjangan, pengalihan hak, perubahan nama atau alamat, pencatatan, pembatalan, penghapusan, petikan, lesensi, banding, dan permohonan lainnya. Kanwil tidak diberikan kewenangan untuk memeriksa atau menerima materi apakah berkas tersebut dapat diterima atau ditolak dan sifat kerjanya hanya menerima berkas untuk kemudian dikirim ke Dirjen HKI dalam waktu 3 (tiga) hari kerja terhitung sejak permohonan diterima.

Pada sisi lain tugas dan fungsi yang dijalankan oleh Kanwil Hukum dan HAM harus berkesinambungan dengan lembaga-lembaga dan atau instansi-instansi di daerah yang juga di berikan amanat melaksanakan tugas tersebut dan berkoordinasi dengan pemerintah pusat yakni Ditjen KI.

Patut diketahui, dinas terkait didaerah sering melakukan program pembinaan terhadap masyarakat lokal UKM, namun program pembinaan yang dilakukan hanya pada hak cipta, paten dan merek saja, sedangkan IG belum seluruhnya tersentuh, padahal IG seharusnya lebih mendapat perhatian karena hak masyarakat berada disana, apalagi sumber daya alam atau produk-produk masyarakat lokal mempunyai reputasi di tingkat daerah, pusat malah internasional. Menurut Idrus23 sebagaian besar pemengku kepentingan didaerah kurang memahami peraran dan strategi dalam pengembangan IG

Pentingnya koordinasi antara pemangku kepentingan pusat dan daerah dalam membangun kesadaran hukum masyarakat lokal bahwa sudah saatnya untuk mereka melindungi sumber daya alamnya dengan sistem IG, sebab IG yang bersumber dari sumber daya alam tersebut mencakup nama kedaerahannya dan sumber daya alam tersebut dapat dipergunakan dalam bidang perdagangan secara nasional maupun internasional.

Soerjono Soekanto24 membagi kesadaran hukum dalam empat indikator yaitu:

1) Pengetahuanhukum,masyarakatdianggapmengetahuiisiuatuperaturanmanakalaperaturan tersebut telah di undangkan;

21 Ibid...Yehezkel Dror, ..h. 170.

22 Ibid wawancara dengan Idrus

23 Wawancara dengan Idrus Ibid

24 Soerjono Soekanto, Kesadaran Hukum dan Kepatuhan Hukum, CV. Radjawa-

li, Jakarta, 1982. hal. 140. 
2) Pamahaman hukum, informsi yang diperoleh dari peraturan tersebut dapat dengan mudah dimengerti oleh warga masyarakat;

3) Sikaphukum,kecenderunganuntukmenerimahukumkarenaadanya penghargaanterhadap hukum sebagai sesuatu yang bermanfaat atau untuk menguntungkan jika hukum itu ditaati;

4) Pola perilaku hukum, apakah peraturan itu berlaku atau tidak dalam masyarakat

Dengan membangun kesadaran hukum yang dilakukan kepada masyarakat akan dilanjuti dengan kepatuhan hukum. Kesadaran dan kepatuhan hukum yang dikaitkan dengan penegakkan hukum oleh W Friedman25 memberi artian sebagai:

1) penegakkan hukum yang sesuai dengan ukuran-ukuran tentang hukum yang baik atau hukum yang buruk;

2) Kepatuhan dari warga-warga masyarakat terhadap kaedah-kaedah hukum yang dibuat serta diterapkan oleh badan-badan legislatif, eksekutif dan yudikatif;

3) Kaedah-kaedah hukum baru harus selaras dengan hak asasi manusia;

4) Negara mempunyai kewjiban untuk menciptakan kondisi-kondisi sosial yang memungkinkan terwujudnya aspirasi-aspirasi manusia dan penghargaan yang wajar terhadap nmartabat manusia;

5) Adanya badan yudukatif yang bebas dan merdeka yang akan dapat memeriksa serta memperbaiki setiap tindakan yang sewenang-wenang dari badan-badan eksekutif dan legislatif.

Peran pemerintah pusat dan daerah haruslah membuat program pembinaan dan pengawasan yang menjangkau masyarakat daerah secara langsung dan berkesinambungan untuk membantu masyarakat, walaupun sistem persyaratannya pada uraian IG dianggap terlalu sulit dan lama, campur tangan pemerintah tetap saja menjadi pendorong untuk masyarakat melakukan pendaftaran agar sumber daya alamnya terlindung dan tidak dimanfaatkan oleh pihak luar.

\section{c.) Faktor Budaya}

Indonesia ialah negara yang berdasarkan atas hukum (rechtsstaat) dan tidak berdasarkan atas kekuasaan belaka (machtsstaat). Ini berarti bahwa sejak kemerdekaan bangsa Indonesia berketetapan untuk memilih bentuk negara hukum sebagai pilihan satu-satunya. Hukum harus menampilkan peran yang sangat mendasar sebagai titik sentral dalam seluruh kehidupan orangperorang, kehidupan masyarakat, maupun kehidupan berbangsa dan bernegara. 26

Ada tiga kewajiban Negara, Pertama, menghargai hak asasi manusia rakyatnya (to respect), Kedua, melindungi hak asasi manusia rakyatnya (to protect), Ketiga, Memenuhi hak asasi manusia rakyatnya (to fulfill). Kewajiban negara haruslah dapat mewujudkan tatanan hukum nasional untuk melindungi hak-hak masyarakat. Arif Sidarta mengusulkan tatanan hukum nasional harus mengandung arti 27:

1) Berwawasan kebangsaan dan berwawasan nusantara;

2) Mampu mengakomodasi kesadaran huum kelompok etnis kedaerahan dan keyakinan keagamaan;

25 W Friedman dalam kutipan Soerjono Soekanto, Kesaran Hukum dan Kepatuhan Hukum. Penerbit CV Radjawali Perkasa, 1982. hal. 149

26 Ismael Saleh, "Pembangunan Cita Hukum dan Penerapan Asas-asas Hukum Nasional Sejak Orde Baru”, Majalah Hukum Nasional, No. 1. Thn 1995, Edisi khusus BPHN, hal 15.

27 Bernard Arif Sidharta, Refleksi tentang Struktur Ilmu Hukum : Sebuah Penelitian tentang Fondasi Kefilsafatan Ilmu Hukum sebagai Landasan Pembangunan Ilmu Hukum Nasional Indonesia, Penerbit Mandar Maju Bandung, 2000, hal 212 
3) Sejauh mungkin berbentuk tertulis dan terunifikasi;

4) Bersifat rasional yang mencakup rasionalitas efisiensi, rasionalitas kewajaran, rationalitas kaidah dan rasionalitas, nilai;

5) Aturanproseduryangmenjamin transparansi,yang memungkinkankajianrasionalterhadap proses pengambilan putusan oleh pemerintah;

6) Responsif terhadap perkembangan aspirasi dan ekspektasi masyarakat.

Berdasarkan apa yang merupakan perwujudan dalam pembangunan hukum maka budaya hukum perlu mendapat prioritas dalam penataan sistem hukum guna membangun sasaran yang ingin dicapai dalam negara hukum. Budaya hukum yang berlaku dalam masyarakat merupakan iklim pikiran dan kekuatan masyarakat yang menentukan bagaimana suatu hukum digunakan, dihindarkan atau disalah gunakan.28 Hukum akan mendapat dukungan sosial apabila hukum tersebut sesuai dengan nilai-nilai sosial yang tumbuh dan berkembang dimasyarakat.29

Untuk melengkapi uraian tentang faktor penyebab masyarakat belum melindungi IG, terungungkap persepsi dan pandangan masyarakat terutama pelaku usaha bahwa selama ini mereka belum mengetahui dan mengenalnya. IG, walaupun ada dibeberapa daerah yang sudah melakukan perlindungan didasarkan dorongan pemerintah pusat maupun daerah untuk mendaftarkannya akan tetapi masih banyak dari masyarakat yang mempunyai sumber daya alam yang belum mereka ketahui dan mengenalnya.

Ketidak tahuan tersebut menjadi salah satunya penyebab faktor budaya masyarakat, dimana masyarakat memang mempunyai prinsip yang bersifat terbuka dan gotong royong atau dikatakan bersifat komunal. Pelaku bisnis atau masyarakat pemerhati KI sulit menerima konsep-konsep KI yang tata cara pendaftaran yang lama dan bersifat kedaerahan, mereka lebih menonjolkan pendaftaran KI yang bersifat hak pribadinya, karena terkait keuntungan yang ingin didapatkan.

Bagi masyarakat lokal, jika ada pihak luar yang meniru hasil karyanya baik dibidang seni, maupun karya lain hal itu tidak menjadi masalah, dan mereka akan merasa bangga apabila pihak lain meniru, memakai ataupun mengambil hasil karyanya dan juga hasil produk lainnya, bagi masyarakat lokal sendiri mereka tidak tahu apa yang akan dilakukan pihak luar baik dalam memanfaatkan dan mengkomersialkan karyanya maupun produknya, walaupun hal itu memperkayakan pihak luar sendiri, karena masyarakat lokal bukanlah masyarakat yang biasa mengkomersialisasi karyanya maupun produknya.

Selain masyarakat penegakan hukum sendiri bekerja belum seksama, dikarenakan budaya dari penegakan hukum sendiri. Idris mengatakan juga penegakan hukum hanya bersifat menunggu pada suatu laporan, padahal prakteknya pengambilan atas produk-produk lokal berpotensi indikasi geografis sudah banyak terjadi30

\section{Bentuk Tanggung Jawab Pemerintah dalam mewujudkan Perlindungan Hukum atas IG}

Negara Indonesia dibangun atas dasar cita-cita yag sangat luhur yakni, demi mencapai masyarakat adil dan makmur. Cita -cita ini secara akademis diistilahkan dengan tujuan negara. Pada alinea IV Pembukaan Undang-Undang Dasar 1945 menegaskan salah satu tujuan negara ung 1980. hal. 85 .

29 Otje Salman dan Anthon F Susanto, Beberapa Aspek Sosiologi Hukum, PT Alumni, Bandung. 2004, hal. 66.

30 Op. Cit. wawancara Idrus 
adalah mewujudkan keadilan sosial bagi seluruh rakyat Indonesia. Paham ini menunjukan bahwa negara kita adalah negara kesejahteraan yang dapat mewujudkan kemakmuran rakyatnya.

Tanggung jawab pemerintah dalam pengertian ini maksudnya membuka pintu bagi masuknya campur tangan negara dalam kehidupan sosial masyarakat. Penerapan KI merupakan bentuk tanggung jawab pemerintah, hal ini timbul dari adanya wewenang dan fungsi pemerintah sebagai alat negara.

Peran negara untuk mewujudkan cita hukum dapat dirumuskan sebagai berikut:31

a. Negara melindungi segenap bangsa Indonesia dan seluruh tumpah darah Indonesia dengan berdasarkan atas persatuan;

b. Negara hendak mewujudkan keadilan sosial bagi seluruh rakyat Indonesia;

c. Negara yang berkedaulatan rakyat, berdasarkan kerakyatan dan permusyawaratan perwakilan;

d. Negara berdasarkan atas Ketuhanan yang maha esa menurut dasar kemanusiaan yang adil dan beradab

Cita perlindungan dengan konsep tanggung jawab pemerintah adalah untuk melindungi seluruh rakyatnya. TRIP's mengakomodasikan negara-negara dengan perangkap hukum negaranya masing-masing, Indonesia turut serta mengaplikasikan UU kekayaan intelektual untuk kepentingan nasional. Dalam perjanjian TRIP's masalah penegakan hukum diatur pada bagian III Pasal, pada Pasal 41 sampai dengan Pasal 61, pada Pasal 41 ayat 1 TRIP's mengatakan bahwa menjadi kewajiban negara peserta menjamin prosedure penegakan hukum yang dapat diterapkan dalam hukum negara peserta perjanjian, seperti dimungkinkannya melakukan tindakan efektif terhadap setiap perbuatan melanggar HKI yang dilindungi perjanjian ini, sedangkan pada Pasal 2 dijelaskan bahwa prosedur penegakan HKI pada Indikasi Geografis harus dilaksanakan secara adil dan setara (fair and equittable).

Upaya penegakan hukum tidak terlepas dari tanggung jawab pemerintah dan pemerintahlah yang membuat mekanisme penetapan sanksi administrasi, denda maupun pidana apabila terjadi pelanggaran atas pemanfaatan Kekayaan Intelektual bangsa Indonesia. Untuk itu penulis mencoba mengambarkan bentuk tanggung jawab pemerintah untuk perlindungan melindungi IG antara lain:

\section{Keikutsertaan Pemerintah Daerah dalam mengelola IG}

Daerah sebagai sumber kekayaan intelektual sangat berperan menjaga dan melindungi sumber daya alam yang berada disekitarnya agar tidak diambil oleh pihak luar untuk memanfaatkan dan melakukan kecurangan atas kekayaan yang ada. Secara konsep, daerah berhak melakukan pengelolaan atas kekayaan intelektual untuk mengidentifikasinya produk yang berpotensi indikasi geografis dari masyarakat.

Pasal 53 UU 20 tahun 2016 ayat (3) menjelaskan indikasi geografis mendapat perlindungan setelah terdaftar atas dasar permohonan yang diajukan oleh :

a. lembaga yang mewakili masyarakat di kawasan geografis tertentu yang mengusahakan suatu barang dan/atau produk berupa:

1. sumber daya alam;

2. barang kerajinan tangan; atau

3. hasil industri.

31 Yoan Nursari Simantjuntak, Hak Desain Industri, Sebuah Realitas Hukum dan Sosial, Srikandi, Surabaya. 2005. Hal. 214. 
b. pemerintah daerah provinsi atau kabupaten/kota.

Pada ayat 3 (b) inilah dibutuhkan keterlibatan pemerintah daerah untuk melindungi produkproduk lokal yang bersumber dari alam yang berada di willayah sekitarnya yang berindikasi geografis untuk di daftarkan dengan sistem pendaftaran indikasi geografis setelah dilakukan penelitian dan penelusuran atas produk lokal yang berpotensi indikasi geografis tersebut.

Dalam memenuhi realisasi pengembangan potensi kekayaan intelektual daerah, tentu saja didukung dengan kebijakan-kebijakan yang strategi dan realisasi, penyediaan sarana dan prasarana yang memadai, jaminan keamanan kepastian hukum serta keterlibatan pemerintah daerah dalam penanganannya.

Pemerintah daerah sebagai tongkat didaerah mempunyai kepentingan dalam rangka mensejahterakan rakyatnya, ini sesuai pesan konstitusional dari UUD 1945, dengan demikian tentu saja memerlukan langkah-langkah realitis dan konkrit bagi seluruh unsur pemangku kepentingan didaerah sesuai tugas dan perannya untuk ikut memberikan kesejahteraan bagi masyarakatnya.

\section{Penegakan Hukum}

Campur tangan pemerintah tidak lepas dari politik suatu negara dimana akan mewujudkan tujuan negara. Tujuan negara Indonesia adalah “...mamajukan kesejahteraan umum...” yang tentunya dipahami sebagai suatu kebijakan yang mengacu pada sistem pasar ekonomi.

Tujuan negara, menurut W. Friedman32 sebagai salah satu pemikir tentang negara kesejahteraan membawa tujuan negara pada negara hukum yang adalah bahwa tujuan negara dalam fungsinya pada masyarakat non totalitarian mengacu pada sistem ekonomi campuran yakni :"to indicate a situation in which the role of goverment as a owner and regulator has became sufficiently largo to cast doubt on a validity of capitalist and free enterpriase as appropriate adjective but not sufficiently large to justify the appellation"sosialist"

Peter Mahmud33 katakan bahwa konsep negara kesejahteraan terkesan regulatoris, tujuan negara untuk mewujudkan kesejahteraan rakyatnya dapat dicapai melalui berbagai cara. Negara dalam upaya mensejahterakan rakyat adalah dengan menciptakan kebijakan yang berorientasi pada sistem ekonomi pasar yang bercirikan :

1. harus memberikan kemudahan

2. harus tidak bersifat intervensi secara berlebihan

3. harus menciptakan aturan yang adil dan jujur

Berlandaskan pada pendapat diatas terlihat peran pemerintah dalam negara adalah bagaimana membawa masyarakatnya menuju pada kesejahteraan rakyatnya sehingga rakyat dapat merasakan peran tersebut. Peran ini tidak terlepas dari pemerintah yang melaksanakan pengawasan atas aturan yang dijalankan.

Bagir Manan menyebutkan bahwa untuk mewujudkan kemakmuran rakyat maka negara harus melaksanakan kewajibannya berupa :34

a. Segala bentuk pemanfaatan (bumi dan air) dan hasil yang didapat (kekayaan alam)harus secara nyata meningkatkan kemakmuran dan kesejahteraan masyarakat

32 W. Friedmann, The State and The Rule of The Law in A Maxed Economy. Steven \& Sons London, 1971. hal 2.

33 Peter Mahmud. Realigning Indonesia Law Concerning Economic Activities Under The State Guedelinnes of 1999. Yuridika, Vol.17.No. 1 tahun 2002.

34 Bagir Manan, Beberapa catatan atas RUU tentang Minyak dan Gas Bumi, FH-Unpad, Bandung Thn 199, pp.. 1-2. 
b. Melindungi dan menjamin segala hak-hak rakyat yang terdapat didalam atau diatas bumi, air dan berbagai kekayaan alam tertentu yang dapat dihasilkan secara langsung atau dinikmati langsung olah rakyat

c. Mencegah segala tindakan dari pihak manapun yang akan menyebabkan rakyat tidak mampunyai kesempatan atau akan kehilangan haknya dalam menikmati kekayaan alam.

Melihat kenyataan yang ada bahwa sebagian besar bangsa kita tidak peduli dengan perkembangan yang terjadi, padahal perkembangan yang terjadi sekarang sangat mempengaruhi bahkan mengancam secara fundamental kehidupan berbangsa dan bernegara, terutama kehidupan pada masyarakat lokal atau adat. Dalam konteks ini negara memegang peranan penting untuk meindungi hak-hak asasi manusia dan warga negaranya termasuk hak-hak adat.

Dari tatanan hukum Indonesia ini terwujud dalam cita hukum pada sistem hukum indonesia sebagaimana yang terkandung dalam Pembukaan UUD 1945 yaltu :

"Melindungi segenap bangsa Indonesia, memajukan kesejahteraan umum, mencerdaskan kehidupan angsa serta ikut melaksanakan ketertiban dunia berdasarkan perdamaian abadai dan keadilan sosial ,... yang berdasarkan kepada Ketuhanan yang Maha Esa, Kemanusiaan yang adil dan beradab, Persatuan Indonesia, Kemanusian yang dipimpin oleh hikmat kebijaksanaan dalam permusyawaratan perwakilan serta Keadilan sosial bagi seluruh rakyat Indonesia"

\section{Perlunya Sosialisasi}

Pada bagian I Pasal 1 dari perjanjian TRIP's terdiri dari ketentuan-ketentuan umum dan prinsip-prinsip dasar. Bagian ini mengisyaratkan setip negara anggotannya untuk mengimplementasikan semua ketententuannya secara penuh dalam peraturan perUndangUndangan nasionalnya. Perjanjian ini memungkin suatu negara anggota untuk menambah kualitas maupun kuantitas perlindungan yang lebih luas akan KI.

Bagi Indonesia. khusus mengenai indikasi geografis dilakukan masih pada tahapan sosialisasi kepada masyarakat. Tujuannya adalah agar peraturan yang ditetapkan diketahui, dipahami dan dilaksanakan. Fiksi hukum bahwa "setiap orang dianggap mengetahui hukum" benar-benar tidak realitik terutama pada masyarakat yang bersifat multi etnik dan agama serta masih jauh dari jangkauan informasi, termasuk informasi hukum.

Sosialisasi diberikan untuk pemahaman yang mendalam tentang aturan yang berlaku dan peran masyarakat akan nampak seperti :

a. sebagai proses penyebaran informasi ;

b. sebagai proses penerangan;

c. sebagai proses transformasi dan ;

d. sebagai proses perubahan perilaku.35

Pendalaman sosialisasi ini diperuntukan terutama apabila adanya intervensi pihak luar kedalam komunitas tertentu. Apalagi dalam perkembangan teknologi dan informasi saat ini di mana sumber daya alam masyarakat lokal menjadi acuan dalam melakukan persaingan tidak sehat guna menguntungkan negara-negara maju.

\section{Pendaftaran untuk melindungi IG.}

Perlindungan atas produk-produk lokal di Indonesia menganut sistem pendaftaran seperti halnya sistem pendaftaran merek yakni first to file, halmana untuk terjaminnya suatu kepastian hukum karena mendapat bukti tulis berupa sertifikat, dimana serifikat yang diberikan mempunyai kekuatan hukum untuk melindungi produk-produk lokal yang didaftarkan pada

35 Lucia Setiana, Teknik Penyuluhan dn Pemeberdayaan Masyarakat, Ghalia Indonesia, 2005, hal.10 
Dirjen HKI Kementerian Hukum dan HAM RI di Jakarata ataupun pada Kantor Wilayah Kementerian Hukum dan HAM yang berada di seluruh wilayah Indonesia.

Timbul pertanyaan mengapa Indikasi Geografis begitu penting untuk mendapat perlindungan? sebab pada dasarnya bahwa banyaknya produk masyarakat lokal diambil oleh pihak luar dan dikomersial untuk mendapatkan keuntungan, oleh karenanya produk-produk lokal sangatlah perlu dilindungi dengan IG untuk mencegah pengambilan yang dilakukan pihak luar. Tentunya untuk melindungi produk-produk masyarakat lokal tersebut masyarakat mempunyai hak milik atasnya dan setidaknya dapat diperuntukan untuk kesejahteraan mereka didaerahnya karena mempunyai nilai ekonomin.

Contoh sebagaimana Indikasi terdaftar dibawah ini (Ditjen KI) :

\begin{tabular}{|c|c|c|c|}
\hline Kopi Robusta Sidi- & $\begin{array}{l}\text { Masyarakat Perlindun- } \\
\text { gan Indikasi Geografis } \\
\text { (MPIG) } \\
\text { Kopi Robusta Sidi- } \\
\text { kalang } \\
\end{array}$ & IG.00.2018.000021 & $\begin{array}{c}\text { ID G } 000000078 \\
\text { (18 Juli 2019) }\end{array}$ \\
\hline Gula Lontar Rote & $\begin{array}{c}\text { Masyarakat Perlindun- } \\
\text { gan Indikasi Geografis } \\
\text { (MPIG) } \\
\text { Gula Lontar Rote }\end{array}$ & IG.00.2017.000014 & $\begin{array}{c}\text { ID G } 000000079 \\
(23 \text { Juli 2019) }\end{array}$ \\
\hline $\begin{array}{l}\text { Kopi Robusta Java } \\
\text { Bogor }\end{array}$ & $\begin{array}{c}\text { Yayasan Masyarakat } \\
\text { Perlindungan Indikasi } \\
\text { Geografis (MPIG) } \\
\text { Java Bogor }\end{array}$ & IG.00.2018.000031 & $\begin{array}{c}\text { ID G } 000000080 \\
(23 \text { Juli 2019) }\end{array}$ \\
\hline $\begin{array}{l}\text { Tenun Doyo Benuaq } \\
\text { Tanjung Isuy Jem- } \\
\text { pang Kutai Barat }\end{array}$ & $\begin{array}{c}\text { Kelompok Masyarakat } \\
\text { Perlindungan Indikasi } \\
\text { Geografis Tenun Doyo } \\
\text { Benuaq } \\
\text { Tanjung Isuy } \\
\text { Jempang Kutai Barat } \\
\text { (KMPIG-TDBJKB) }\end{array}$ & IG.00.2018.000028 & $\begin{array}{l}\text { ID G } 000000081 \\
\text { (13 Agustus 2019) }\end{array}$ \\
\hline
\end{tabular}

Jeremmy Bantham penggegas Utility mengatakan tugas pemerintah adalah meningkatkan kebahagian masyarakat dengan memperbesarkan kesenangan yang dapat dinikmati masyarakat dan memungkinkan terciptanya keamanan dengan mengurangi penderitaan.36

Berkaitan dengan sistem pendaftaran, indikasi geografis juga merupakan hak milik yang mememiliki nilai ekonomis sehingga perlu mendapat perlindungan hukum, dimana perlindungan hukum yang diberikan memenuhi beberapa syarat standarisasi yang antara lain:

Pertama, indikasi geografis merupakan tanda pengenal atas barang yang berasal dari wilayah tertentu atau nama dari barang yang dihasilkan dari suatu wilayah tertentu dan secara tegas tidak bisadipergunakan untuk produk sejenis yang dihasilkan dari wilayah lain.

36 Bodenheimer, Edgar, Jurisprudence : The Philosophy and Method of the Law, Harvard University Press, Cambridge, Massachusetts, 1962. hal 33.

322 Maria Alfons | Tanggung Jawab Pemerintah Atas Perlindungan Hukum Geografis ... 
Kedua, indikasi geografis merupakan indikatorkualitas, indikasi geografis menginformasikan kepada konsumen bahwa barang tersebut dihasilkan dari suatu lokasi tertentu dimana pengaruh alam sekitar menghasilkan kualitas barang dengan karakteristik tertentu yang terus dipertahankan reputasinya.

Ketiga, indikasi geografis merupakan kepentingan bisnis dimana indikasi geografis memberikan nilai tambah komersial terhadap produk dan meningkatkan perdagangan

Keempat, berdasarkan perjajian TRIPs indikasi geografis merupakan hak milik intelektual yang dapat dipertahankan haknya dari segala tindakan melawan hukum dan persaingan.

Dengan diberlakukannya PP. 51 Tahun 2007 pada tanggal 4 September 2007 sebagai aturan pelaksanaan dari Undang-Undang Nomor 20 Tahun 2016 membuka jalan untuk dapat didaftarkannya sesuai tata cara pendaftaran atas IG

\section{Pendokumentasian untuk melindungi produk-produk masyarakat lokal}

Persoalan yang penting yang dapat dilakukakam oleh pemerintah untuk melindungi kekayaan sumber daya alam yang merupakan produk masyarakat lokal dari parsaingan curang yang dilakukan oleh pihak luar adalah bagaimana pendokumentasian atas produk-produk masyarakat lokal dapat disusun, sehingga dapat dilihat manfaatnya secara maksimal dan dapat efektif.

Dokumentasi adalah merupakan suatu sarana yang dapat digunakan sebagai alat bukti dalam mempertahankan permasalahan apabila terjadi suatu tuntutan yang dilakukan pihak asing untuk memanfaatkan sumber daya alam milik masyarakat lokal.

Meskipun dokumentasi mungkin tidak ekonomi dan efektif sebagai sarana perlindungan, akan tetapi dalam percaturan global dokumentasi menjadi sesuatu yang dapat diselesaikan dan terhindar bila pemerintah akan mengajukan klaim perlindungan terhadap indikasai geografis, apalagi negara-negara maju menawarkan dokumentasi sebagai salah satu jalan alternatif untuk memberikan perlindungan.

Tuntutan untuk memberikan perlindungan terhadap produk-produk masyarakat lokal adalah merupakan satu tindakan mempertahanankan hak masyarakat terhadap sumber daya alam, namun disatu sisi perlu dipertanyakan apakah sumber daya alam masyarakat lokal sudah mempunyai reputasi, hal ini sangat dikuatirkan untuk menjawabnya karena selama ini reputasi terhadap produk lokal masyarakat Indonesia rata-rata belum dapat dikatakan mempunyai reputasi sebab bangsa Indonesia dalam pemeiliharaan akan sumber daya alam lokal hanya dipergunakan pada kepentingan bersama masyarakat setempat dan terbuka bagi pihak luar, apabila dibutuhkan oleh pihak luar atas pemakaian produk tersebut.

Oleh karena itu sudah saatnya negara berkembang seperti Indonesia untuk melindungi produk-produk masyarakat lokal dari negara-negara maju terhadap pengambilan sumber daya alam maupun kerajinan industri masyarakat lokal sendiri, dan ini dapat dilakukan hanya dengan menggunakan sistim pendaftaran yang dianggap sebagai perlindungan terhadap KI milik masyarakat lokal dan dibantu oleh instansi atau lembaga-lembaga yang pemerhati Indikasi Geografis sebagaimana tertera dalam perUndang-Undangannya.

Dalam konteks ini barangkali pentingnya kerjasama antar pemerintah baik pusat maupun daerah dan masyarakat serta lembaga-lembaga atau asosiasi pemerhati IG untuk mempunyai kepedulian terhadap masalah perlindungan hak masyarakat atas indikasi geografinya, dan keterbukaan atas sumber daya alam dari masyarakat lokal untuk meminta perlindungan sehingga sumber daya alamnya terlindung dari misappropriation. 


\section{KESIMPULAN}

Indikai Geografis merupakan suatu konsep kekayaan intelektual yang sudah lama ada dan mengalami perkembangan secara terus menerus karena adanya kegiatan ekonomi dunia yang didasarkan dari adanya konvensi inernasional untuk melindunginya. Perlindungan yang dilakukan oleh pemerintah didasarkan pada tanggung jawab untuk melindungi sumber daya alam yang berada di wilayah masyarakat lokal, namun pada akhir-akhir ini kekayaan intelektual yang merupakan sumber daya alam masyarakat lokal diambil dan dipakai oleh negara luar yang kemudian munculnya persaingan curang.

Dari banyaknya permasalahan yang terjadi atas sumber daya alam yang berada diwilayah Negara kita, maka sepatutnya dilakukan pendaftaran untuk melindungi hak masyarakat yang dilatar belakangi dengan bunyi Pasal 33 UUD 1945, dan pemerintah harus turut serta membantu masyarakat lokal untuk mewujudkan kesejahteraan kepada rakyat. Adapun perlindungan akan kekayaan intelektual dimaknai dengan tanggung jawab pemerintah dalam mengelola sumber daya alam yang tertuang dalam makna " dikuasai oleh negara dan dipergunakan untuk sebesar-besarnya kemakmuran rakyat " dengan begitu negara memberikan kesempatan untuk pemerintah melaksanakan pengelolaan dan pembinaan atas sumber daya alam milik masyarakat dan memberikan kesejahteraan bagi rakyatnya.

Pada prinsipnya perlindungan atas indikasi geografis memberikan hak ekonomi bagi masyarakat didaerah manakala sumber daya alamnya mampu dikelola dengan baik oleh mereka dan keikut sertaan pemerintah dalam menjaga dan mengawasinya sebagai bentuk tanggung jawab, sebab pada penjelasan Pasal 33 UUD 1945 menyatakan perekonomian atas demokrasi ekonomi, dan kemakmuran bagi semua orang. Sebab itu cabang-cabang produksi yang penting bagi negara dan yang menguasai hayat hidup orang banyak harus dikuasai oleh negara dan dipergunakan sebesar-besarnya untuk kemakmuran rakyat.

\section{DAFTAR PUSTAKA}

UU. No 20 Tahun 2016.

Pengaturan Indikasi Geografis dalam UU No. 20 Tahun 2018 tentang Merek dan IG, diatur pada Bab VII Pasal 53 sampai dengan Pasal 63.

"The WTO Was Born Out of Negotation, everything the WTO does is the result negotiation “, < http: //www.wto.org> Supanto “ Pembentukan TRIP”s sebagai penetrasi budaya “. Dalam Wajah Hukum dalam Era Reformasi ( Kumpulan Karya Ilmiah Menyambut 70 Thn Prof.Dr Sutjipto Raharjo, SH) Citra Aditya Bhakti, Bandung, 2000, hal 279.

The Agreement of the Trade Aspects of Intellectual Property Right, Including Trade in Counterfeit Good ( TRIP'S) Agreement) World Trade Organization 1994, article. 22.1.

Delphine Marie-Vivvien." Geographical Indication and International Legal Framework". Dalam Liputsan Khusus, Media HKI. Vol.II/No.1/April 2004, hal.29.

United States Patent and Trademark Office. (http://tess.uspto.gov/bin/gate. exe? $\mathrm{f}=$ doc\&state $=$ fnd $8 \mathrm{p} 9.2 .3$ )

K.W. Saleh, Seminar Hukum Nasional, Ghalia Indonesia, Jak. 1963-1979. Thn 1980. hal. 80.

Satjipto Rahardjo. Ilmu Hukum. Penerbit Alumni, Bandung, 1982, h. 20 
Philipus M. Hadjon. 1987. Perlindungan Hukum Bagi Rakyat Indonesia, PT. Bina Ilmu, Surabay, p.2.

Ronny, Hanitijo Soemitro. Metodologi Penelitian Hukum. Ghalia Indonesia, Jakarta, 1982,h. 72

Denis Rochart, La Protection Internationale des Indications Geographiques, Presses Universitaires de France, Paris, 2002, hal.359.

Emawati Junus, Seminar IG ke Dirjen HKI, Tgl 6-7 Thn 2004 Kerjasama Ditjen HKI dan ECASEAN Cooperation on Intellectual Property Right (ECAP) II

Abdul Bari Azed, Kepentingan Negara Berkembang terhadap IG, Sumber Daya Genetik dan Pengatahuan Traditional, Lembaga Pengkajian Hukum International Fak Hukum UI kerjasama dengan Ditjen HKI, Thn 2005, Hal 11.

Saphor Manulu Hutagalung, Hak Cipta dan Penerapannya didalam Pembangunan. Akademi Prasindo.Jakarta. 2000. hal. 94

Philipus M. Hadjon. 1987. Perlindungan Hukum Bagi Rakyat Indonesia, PT. Bina Ilmu, Surabay, p.2.

L. M. Friedman, TheLegal System: A Social Science Perpektive, Russel Sage Foundation New York, 1977. hal 153

Yehezkel Dror,Ventures and Policy Scince Conceptsand Application, New York, Elsevier, 1981. hal 170.

Soerjono Soekanto, Kesadaran Hukum dan Kepatuhan Hukum, CV. Radjawali, Jakarta, 1982. hal. 140.

W Friedman dalam kutipan Soerjono Soekanto, Kesaran Hukum dan Kepatuhan Hukum. Penerbit CV Radjawali Perkasa, 1982. hal. 149

Ismael Saleh, "Pembangunan Cita Hukum dan Penerapan Asas-asas Hukum Nasional Sejak Orde Baru”, Majalah Hukum Nasional, No. 1. Thn 1995, Edisi khusus BPHN, hal 15.

Bernard Arif Sidharta, Refleksi tentang Struktur Ilmu Hukum : Sebuah Penelitian tentang Fondasi Kefilsafatan Ilmu Hukum sebagai Landasan Pembangunan Ilmu Hukum Nasional Indonesia, Penerbit Mandar Maju Bandung, 2000, hal 212

Satjipto Rahardjo, Bekerjanya Hukum dalam dan masyarakat. Angkasa, Bandung 1980. hal. 85.

Otje Salman dan Anthon F Susanto, Beberapa Aspek Sosiologi Hukum, PT Alumni, Bandung. 2004, hal. 66 .

Yoan Nursari Simantjuntak, Hak Desain Industri, Sebuah Realitas Hukum dan Sosial, Srikandi, Surabaya. 2005. Hal. 214.

W. Friedmann, The State and The Rule of The Law in A Maxed Economy. Steven \& Sons London, 1971. hal 2.

Peter Mahmud. Realigning Indonesia Law Concerning Economic Activities Under The State Guedelinnes of 1999. Yuridika, Vol.17.No. 1 tahun 2002.

Bagir Manan, Beberapa catatan atas RUU tentang Minyak dan Gas Bumi, FH-Unpad, Bandung Thn 199, pp.. 1-2.

Lucia Setiana, Teknik Penyuluhan dn Pemeberdayaan Masyarakat, Ghalia Indonesia, 2005, 
hal.10

Bodenheimer, Edgar, Jurisprudence : The Philosophy and Method of the Law,

Harvard University Press, Cambridge, Massachusetts, 1962. hal 33. 